\title{
Optimal Investment Timing under A Mean-reverting Process: A Real Options Approach*
}

\author{
Yuta Fukui ${ }^{\mathrm{a}} \quad$ Junichi Imai ${ }^{\mathrm{b}, \dagger}$ \\ ${ }^{a}$ Graduate School of Science and Technology, Keio University \\ ${ }^{\mathrm{b}}$ Faculty of Science and Technology, Keio University
}

\begin{abstract}
This paper investigates the optimal entry and exit decisions under a mean-reverting process over a finite horizon. Many theoretical studies on real options assume that an underlying risk follows a geometric Brownian motion over an infinite-time horizon. This assumption is not always practical, especially in discussing realistic investment strategies. In this paper, we examine effects of the mean-reverting process on both entry and exit decisions over a finite horizon. We focus on deriving the optimal boundaries of entry and exit decisions under a mean-reverting process, and compare the effects of the underlying risk process and length of the project horizon on the optimal decisions. Numerical examples in this paper demonstrate that the length of horizon could have a significant impact on the boundaries of the optimal decisions, and hence on project values, particularly under a mean-reverting process.
\end{abstract}

Keywords: Real options; Mean-reverting processes; Investment timing; Finite horizon

\footnotetext{
* Received: March 27, 2015; Accepted: October 28, 2015

${ }^{\dagger}$ Corresponding author. Address: 3-14-1 Hiyoshi, Yokohama, Kanagawa, 223-8522, Japan; Phone: +81-45-566-1621; E-mail: jimai@ae.keio.ac.jp
} 


\title{
リアルオプションアプローチによる 平均回帰過程の下での投資タイミングの分析
}

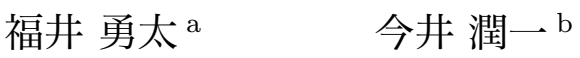 \\ $a$ 慶應義塾大学大学院理工学研究科 \\ $\mathrm{b}$ 慶應義塾大学理工学部
}

\section{1 序論}

グローバル化や IT 技術の発展により，我々を取り巻く環境は複雑さを増していて，将来を正確に予 測することは困難である。この状況は，企業がプロジェクトへ投資を行うときにも関係することで，企 業は予測が難しい不確実性を伴う中での意思決定が求められる。また，その意思決定は，将来の状況に よって柔軟に変更していく必要がある．例えば，企業が新しい市場へ参入しょうとする場合を考えると， 参入する条件は参入後ある一定以上の収益を持続して得られることであり，その条件を満たすであろう と判断できたときに参入する。そして，計画された生産を行っていくが，ときには需要の変化などから 計画を変更しなければならない場面もある。また，R\&D (research and development)のような長期間に わたる段階的なプロジェクトに関しても同様のことが言える。開発を行うときには，生産技術の進歩や 予想収益，競争企業の状況を考慮して，開発からの撤退を含め各段階でどれだけの投資を行うかを判断 しなければならない。これらのプロジェクトのように多くの場合，投資を行うことは不確実な状況下で の決定を強いられ，その決定は状況に応じて変化させることが求められる.

これまで，リアルオプションアプローチを投資意思決定に適用してきた研究は, Dixit [2] や McDonald and Siegel [4]のように不確実である商品の価格やプロジェクトの価值を幾何ブラウン運動に従うと仮定 する場合が多い. 確かに幾何ブラウン運動を仮定することで得られる解析面での利点は多い。しかし，コ モディティのような需要と供給によって価格が変化するような原資産を考えると，商品の価格が下がれ ば需要が上がり，そして商品の価格を上げると需要は下がる，といったサイクルが続くであろう。した がって，価格はある一定の数值に回帰するような変動をする。これは，不確実性が従う確率過程を幾何 ブラウン運動ではなく，平均回帰過程と仮定することが望ましい状況が存在することを示している．実 際に Bessembinder et al. [1] や諸田 [9] では平均回帰性の存在を主張しており, 発電所の開発や原油の 採掘のプロジェクトには平均回帰性が大きな影響を与えると考えられる。しかしながら, 平均回帰性に 注目した研究は少ないのが現状である。その中で，平均回帰過程に言及している代表的な研究としては Metcalf and Hassett [5] と Tsekrekos [7]が挙げられる.

Metcalf and Hassett [5] では企業の不可逆な参入の問題を平均回帰過程の下で議論しており，平均回 帰性の 2 つの特徵を主張している。まず1つ目は，“variance effect'と呼ばれるものであり，平均回帰過 程を用いることで長期的な視点で考えると価格の変動が小さくなり参入の境界が下がることを意味する. 2 つ目は，'realised effect' と呼ばれるものであり，平均回帰性により変動が小さくなることで参入の境 界に達しづらくなることを意味する。これら 2 つの相反する効果がお互いを打ち消しあうことで，平均 
回帰性は大きな影響を及ぼさないと結論づけている。 また，Tsekrekos [7]では，参入だけではなく撤退 を含んだ投資夕イミングの分析を行っている，撤退を考慮した場合においても 'variance effect,' 'realised effect,'さらに Sarkar [6] で述べられている 'risk discounting effect' (平均回㷌性によりプロジェクトの システマティックリスクが下がる効果）が存在することを示し, 参入と撤退の問題に拡張可能であるこ とを示した. Tsekrekos [7]の結論として, パラメータに依存する部分は大きいが, 平均回帰過程は参入 と撤退に関して大きな影響を及ぼすことが示唆されている。これらの先行研究の共通点として, 企業の 意思決定に関して無限期間で分析されていることが挙げられる。しかし，企業の問題を考える場合，プ ロジェクトの期間が無限であるという状況は限定的なものであり, 現実的とは言えない.

そこで本研究では, より現実的かつ一般的な状況での分析を行うために, 有限期間において平均回帰 過程が参入と撤退に与える影響を分析可能なモデルを構築し考察を行う.モデルの構築にあたり, 今井 [8] で述べられているリアルオプションを評価する際に有効なフレームワークであるスイッチングオプ ションと Longstaff and Schwartz [3] により提案されたアメリカンオプションの評価法である最小二乗 モンテカルロ法を利用する. 本モデルでは数值解の導出を行い, 数值実験の結果から有限期間の問題を 無限期間で議論するとプロジェクトの価值を過大評価してしまうこと, さらには有限期間でも平均回帰 過程は企業の意思決定に影響を及ぼすことを明らかにする。

本研究は以下のような構成となっている，2節では，スイッチングオプションと最小二乗モンテカル ロ法の理論と評価法を紹介し, 本研究のモデルを説明する．３節では，2節で説明したモデルを用いて数 值実験を行い, 有限期間で分析する必要性と平均回帰過程の特徵を明らかにする．最後に 4 節では, 結 論を述べる。

\section{2 モデル}

本節では，本研究で扱う企業のプロジェクトを説明するとともに，プロジェクトを評価するためのモ デルについて説明する．2.1節では，企業のプロジェクトに対する仮定を置く．2.2節ではスイッチング オプション, 2.3 節では最小二乗モンテカルロ法のモデルへの適用について示す。そして, 2.4 節では企 業の投資タイミングとプロジェクトの価值の導出について述べる.

\section{1 仮定}

本研究では，企業が新商品を生産するプロジェクトを保有している場合の最適な参入夕イミングと参 入後の最適な撤退タイミングを数值的なアプローチを用いて導出する。一般的に，企業は設備投資など の参入によるコスト，さらに商品を生産するコストを考慮しても十分な利益を得られると判断した場合 に参入を行う。また，参入後は商品の価格が生産コストを下回るような，生産による利益が望めない状 況になったときに撤退を行う。本研究では，このプロジェクトは以下の仮定に従っているとする。まず, 企業は 1 年間につき 1,000 回の意思決定の機会を持ち, 連続的な意思決定が可能であるとする（付録 $\mathrm{A}$ 参照).この意思決定の時点を $t(t=1,2, \ldots, T)$ と書くと, 企業が生産しょうとしている商品の価格 $P_{t}$ は

$$
d P_{t}=\kappa\left(\theta-P_{t}\right) d t+\sigma P_{t} d z_{t},
$$

の平均回帰過程に従っているとする。(1) 式の $\theta$ は $P_{t}$ の長期平均, $\kappa$ は長期平均に回帰する強さ, $z_{t}$ は 標準ブラウン運動， $\sigma$ は確率項のボラティリティとする. また， $\theta \geq 0, \kappa \geq 0$ (ただし， $\kappa=0$ の場合は 幾何ブラウン運動となる) , $\sigma>0$ を満たすものとする. 企業は参入する場合, 参入コスト $K_{1}$ を支払わ 


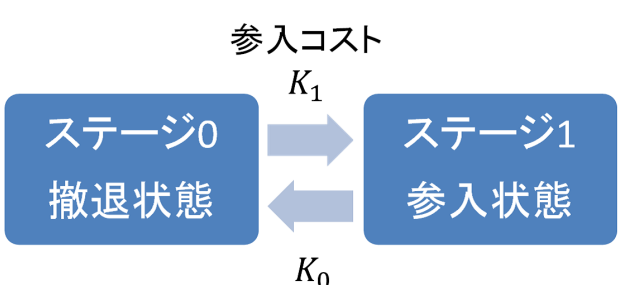

撤退コスト

図 1: 本研究におけるスイッチングオプションの図

なければならない. 実際の状況を考えても, 最初は生産するための設備投資等が必要であるので, コス トを支払うことは妥当である．同様に撤退する場合にも撤退コスト $K_{0}$ が伴うとする．参入後は価格 $P_{t}$ の商品を生産コスト $c$ で生産するとし， $P_{t}-c$ のキャッシュフローを得ることが出来る。これら 3 種類 のコストは一定とする。

\section{2 参入と撤退のタイミング}

本節では，企業の参入と撤退のタイミングについて説明する．企業が参入を決定する夕イミングは，参 入コストを支払う必要はあるが，生産した場合に得られる利益が十分大きいと考えられるまで価格が上 昇したときである。また，企業が撤退を決定する夕イミングは，撤退コストを支払う必要はあるが，生 産した場合に発生する損失を被るよりは好ましいと考えられるまで価格が下落したときである。この参 入や撤退を決める価格は, 企業が意思決定を行う時点によって変わることが予想でき, 各時点での価格 を知ることは企業の最適な投資夕イミングを見つけることを可能にする．本モデルでは，企業の参入と 撤退のタイミングをスイッチングオプションを用いて求める.

スイッチングオプションとはスイッチングコストを支払うことで他の状態へ移行する権利を持ったオ プションの総称である. スイッチングオプションはステージ数とスイッチングコストを変化させること で, R\&Dのような多くのステージを持つプロジェクトにも応用でき，多くのリアルオプションを評価す ることが可能となる.

ここで, 本研究の問題にスイッチングオプションのフレームワークを当てはめる. 本モデルでは, 参 入状態と撤退状態という 2 つのステージがあると仮定する. 企業は意思決定を行う時点 $t$ において，ス テージを移行するか同じステージに留まるかを決定する。なお，意思決定を行う前にキャッシュフロー が発生し, 移行後のステージでのキャッシュフローは次の時点で受け取るものとする. ステージ 0 を撤退 状態, ステージ 1 を参入状態とすると, ステージ 0 からステージ 1 へ移行するためのコストとして参入 コスト $K_{1}$, ステージ 1 からステージ 0 へ移行するためのコストとして撤退コスト $K_{0}$ が必要とする。 コ ストを支払うことで，企業は期間中に何度でもステージを移行することができる．この概要を図で示す と図 1 のようになる.

次に本研究のスイッチングオプションにおけるステージの移行について説明する。 まず, 時点 $t$ にお けるステージ $j$ での意思決定後の価值を $V_{A}\left(P_{t}, j\right)$, 意思決定前の価值を $V_{B}\left(P_{t}, j\right)$ とする. 意思決定後の 価值 $V_{A}\left(P_{t}, j\right)$ は，次の時点での価值で表すことができるので

$$
V_{A}\left(P_{t}, j\right)=e^{-r d t} E_{t}^{Q}\left[V_{B}\left(P_{t+1}, j\right)\right], \quad(j=0,1),
$$

と表すことができる。ここで， $d t$ は意思決定の間隔， $r$ は安全利子率, $E_{t}^{Q}[\cdot]$ はリスク中立確率のもとで の時点 $t$ における期待值であり, 時点 $t+1$ 以降に企業が最適な意思決定をした場合の時点 $t$ での期待值 
である。また，満期時点 $T$ では次に時点が存在しないので

$$
V_{A}\left(P_{T}, 0\right)=V_{A}\left(P_{T}, 1\right)=0
$$

と書ける．また，意思決定前についてはステージ 1 の場合にのみキャッシュフローが発生するので

$$
\begin{aligned}
& V_{B}\left(P_{T}, 0\right)=\max \left(V_{A}\left(P_{T}, 0\right), V_{A}\left(P_{T}, 1\right)-K_{1}\right)=0, \\
& V_{B}\left(P_{T}, 1\right)=P_{T}-c+\max \left(V_{A}\left(P_{t}, 1\right), V_{A}\left(P_{T}, 0\right)-K_{0}\right)=P_{T}-c
\end{aligned}
$$

と書ける。

最初に，ステージ 0 の場合を考える。 ステージ 0 での意思決定前においては，ステージ 0 に留まるか， ステージ 1 に移行するかの 2 つの選択肢がある，ステージ 0 ではキャッシュフローが発生せず，ステー ジ 1 に移行する場合は参入コストが必要なので, ステージ 0 での意思決定前の価值 $V_{B}\left(P_{t}, 0\right)$ は

$$
V_{B}\left(P_{t}, 0\right)=\max \left(V_{A}\left(P_{t}, 0\right), V_{A}\left(P_{t}, 1\right)-K_{1}\right)
$$

と書ける.すなわち, $V_{A}\left(P_{t}, 0\right) \geq V_{A}\left(P_{t}, 1\right)-K_{1}$ ならばステージ 0 に留まり, $V_{A}\left(P_{t}, 0\right)<V_{A}\left(P_{t}, 0\right)-K_{1}$ ならばステージ 1 に移行する. 次に, ステージ 1 の場合を考える. ステージ 1 での意思決定前において も，ステージ 1 に留まるか，ステージ 0 に移行するかの 2 つの選択肢がある. ステージ 1 では生産する ことにより $P_{t}-c$ のキャッシュフローが発生し, ステージ 0 に移行する場合は撤退コストが必要なので, ステージ 1 での意思決定前の価值 $V_{B}\left(P_{t}, 1\right)$ は

$$
V_{B}\left(P_{t}, 1\right)=P_{t}-c+\max \left(V_{A}\left(P_{t}, 1\right), V_{A}\left(P_{t}, 0\right)-K_{0}\right)
$$

と書ける.したがって, $V_{A}\left(P_{t}, 1\right) \geq V_{A}\left(P_{t}, 0\right)-K_{0}$ ならばステージ 1 に留まり, $V_{A}\left(P_{t}, 1\right)<V_{A}\left(P_{t}, 0\right)-K_{0}$ ならばステージ 0 に移行する.

ここで, 価格が格子モデルに従っているとすると, (2) 式は時点 $T$ から後退的に求めることで計算で きる場合がある。しかし, 本研究のようにシミュレーションベースでアプローチするときは, この期待 值をどのように求めるかが問題となる。そのため 2.3 節において, シミュレーションベースでの期待值 計算の方法を説明する.

\section{3 期待值の導出}

本研究では，(2) 式で表される期待值の算出に Longstaff and Schwartz [3] で提案されている最小二乗 モンテカルロ法（以下，LSM と記す）を用いる，LSM はシミュレーションによるアメリカンオプショ ンの価格評価法として提案された手法である. LSMではアメリカンオプションの価值が最大となる時点 を求めることを目的としており, 将来のキャッシュフローの期待值を各時点の原資産の状態から近似し 本源的価值と比較することで行使時点を決定する。詳しくはLongstaff and Schwartz [3] を参照すると 良い. 以下に, 本研究において LSM の考えを用いた期待值算出のアルゴリズムをまとめる.

\section{期待値算出のアルゴリズム}

(i) 初期時点から満期時点まで, 各時点での商品の価格パスを $L$ 本発生させる. 
(ii) 各パス $\omega_{i}(i=1,2, \ldots, L)$ の時点 $t$, ステージ $j$ での意思決定前の価值を $V_{B}\left(P_{t}\left(\omega_{i}\right), j\right)$, 意思決定後 の価值を $V_{A}\left(P_{t}\left(\omega_{i}\right), j\right)$ と書く. まず各パスについて, 満期時点 $T$ では 2.2 節で示したように,

$$
\begin{aligned}
& V_{A}\left(P_{T}\left(\omega_{i}\right), 0\right)=V_{A}\left(P_{T}\left(\omega_{i}\right), 1\right)=0, \\
& V_{B}\left(P_{T}\left(\omega_{i}\right), 0\right)=\max \left(V_{A}\left(P_{T}\left(\omega_{i}\right), 0\right), V_{A}\left(P_{T}\left(\omega_{i}\right), 1\right)-K_{1}\right)=0, \\
& V_{B}\left(P_{T}\left(\omega_{i}\right), 1\right)=P_{T}\left(\omega_{i}\right)-c+\max \left(V_{A}\left(P_{t}\left(\omega_{i}\right), 1\right), V_{A}\left(P_{T}\left(\omega_{i}\right), 0\right)-K_{0}\right)=P_{T}\left(\omega_{i}\right)-c,
\end{aligned}
$$

と書ける。

（iii）次に時点 $T-1$ において意思決定後の価值 $V_{A}\left(P_{T-1}\left(\omega_{i}\right), j\right)$ を求める. ステージ 0 の場合は, $V_{B}\left(P_{T}\left(\omega_{i}\right), 0\right)=0$ なので

$$
V_{A}\left(P_{T-1}\left(\omega_{i}\right), 0\right)=0,
$$

である，ステージ 1 の場合は，意思決定後の価值を求めるために，LSM の考えから $P_{T-1}$ を用い て $E_{T-1}^{Q}\left[V_{B}\left(P_{T}\left(\omega_{i}\right), 1\right)\right]$ の值を多項式で近似する. 具体的には, 基底関数を

$$
\phi(x, l)=x^{l}, \quad l=0,1, \ldots, n,
$$

とすると, 各パス $\omega_{i}(i=1,2, \ldots, L)$ について,

$$
\min _{a_{T-1}(l), l=0,1, \ldots, n} \sum_{i=1}^{L}\left(e^{-r d t} V_{B}\left(P_{T}\left(\omega_{i}\right), 1\right)-\sum_{l=0}^{n} a_{T-1}(l) \phi\left(P_{T-1}\left(\omega_{i}\right), l\right)\right),
$$

を解く.そして, 回帰係数 $a_{T-1}^{*}(l)(l=0,1, \ldots, n)$ を求め, 意思決定後の価值を

$$
V_{A}\left(P_{T-1}\left(\omega_{i}\right), 1\right)=\sum_{l=0}^{n} a_{T-1}^{*}(l) \phi\left(P_{T-1}\left(\omega_{i}\right), l\right),
$$

と近似する。したがって, 意思決定前の価値

$$
\begin{aligned}
& V_{B}\left(P_{T-1}\left(\omega_{i}\right), 0\right)=\max \left(V_{A}\left(P_{T-1}\left(\omega_{i}\right), 0\right), V_{A}\left(P_{T-1}\left(\omega_{i}\right), 1\right)-K_{1}\right), \\
& V_{B}\left(P_{T-1}\left(\omega_{i}\right), 1\right)=P_{T-1}\left(\omega_{i}\right)-c+\max \left(V_{A}\left(P_{T-1}\left(\omega_{i}\right), 1\right), V_{A}\left(P_{T-1}\left(\omega_{i}\right), 0\right)-K_{0}\right),
\end{aligned}
$$

を計算することが可能となる.

(iv) 一般的に, 時点 $t$ の場合を考える. ステージ 0 にいるとき, 意思決定後の価值 $V_{A}\left(P_{t}\left(\omega_{i}\right), 0\right)$ は $V_{B}\left(P_{t+1}\left(\omega_{i}\right), 0\right)$ が既知であるので

$$
\min _{b_{t}(l), l=0,1, \ldots, n} \sum_{i=1}^{L}\left(e^{-r d t} V_{B}\left(P_{t+1}\left(\omega_{i}\right), 0\right)-\sum_{l=0}^{n} b_{t}(l) \phi\left(P_{t}\left(\omega_{i}\right), l\right)\right),
$$

を解くことで

$$
V_{A}\left(P_{t}\left(\omega_{i}\right), 0\right)=\sum_{l=0}^{n} b_{t}^{*}(l) \phi\left(P_{t}\left(\omega_{i}\right), l\right),
$$

と近似できる。同様にステージ 1 にいる場合も，

$$
\min _{a_{t}(l), l=0,1, \ldots, n} \sum_{i=1}^{L}\left(e^{-r d t} V_{B}\left(P_{t+1}\left(\omega_{i}\right), 1\right)-\sum_{l=0}^{n} a_{t}(l) \phi\left(P_{t}\left(\omega_{i}\right), l\right)\right),
$$


を解くことで

$$
V_{A}\left(P_{t}\left(\omega_{i}\right), 1\right)=\sum_{l=0}^{n} a_{t}^{*}(l) \phi\left(P_{t}\left(\omega_{i}\right), l\right),
$$

と近似できる。この意思決定後の值を用いて, 意思決定前の価值

$$
\begin{aligned}
& V_{B}\left(P_{t}\left(\omega_{i}\right), 0\right)=\max \left(V_{A}\left(P_{t}\left(\omega_{i}\right), 0\right), V_{A}\left(P_{t}\left(\omega_{i}\right), 1\right)-K_{1}\right), \\
& V_{B}\left(P_{t}\left(\omega_{i}\right), 1\right)=P_{t}\left(\omega_{i}\right)-c+\max \left(V_{A}\left(P_{t}\left(\omega_{i}\right), 1\right), V_{A}\left(P_{t}\left(\omega_{i}\right), 0\right)-K_{0}\right),
\end{aligned}
$$

を計算することが可能となる。

（v）以上のプロセスを後退的に繰り返し, 初期時点まで行う.その結果, 各時点・各ステージでの価值 を求めることができる.

\section{4 企業の参入と撤退の境界とプロジェクトの価値}

本節では， 2.2 節， 2.3 節の方法から企業の参入と撤退のタイミングとその境界，プロジェクトの価值 を導出する.

第 1 に，参入と撤退のタイミングついては，まず $L$ 本の価格パスを発生させる，次に，各ステージ・ 各時点の $V_{A}\left(P_{t}, j\right)$ を各時点の価格から近似し後退的に計算する. 本研究の問題は企業の参入を考えてい ることから, 初期時点ではステージ 0 にいるとする。 したがって, 各パス $\omega_{i}$ について初期時点から (3) 式より $V_{A}\left(P_{t}\left(\omega_{i}\right), 0\right)$ と $V_{A}\left(P_{t}\left(\omega_{i}\right), 1\right)-K_{1}$ を比較することで参入の時点と価格を求め, 同様に (4) 式よ り $V_{A}\left(P_{t}\left(\omega_{i}\right), 1\right)$ と $V_{A}\left(P_{t}\left(\omega_{i}\right), 0\right)-K_{0}$ の比較から撤退の時点と価格を求める. 参入状態か撤退状態かを 判断し，以上のプロセスを繰り返すことで，参入と撤退のタイミングを求めることが可能となる.

第 2 に，参入と撤退の境界の導出を行う。参入に関しては価格が高くなったときに起こるので，パス ごとに参入時点と価格を求めた結果，同じ時点において参入するパスが複数ある場合には一番低い価格 を参入の境界とする。同様に，撤退に関しては価格が低くなったときに起こるので，パスごとに参入時 点と価格を求めた結果, 同じ時点において撤退するパスが複数ある場合には一番高い価格を撤退の境界 とする。したがって，参入と撤退の境界を以下の様なアルゴリズムで導出する.

\section{参入と撤退の境界のアルゴリズム}

(i) 全パスについて, 参入と撤退の時点と価格を求める.

(ii) 求めた時点と価格を散布図としてプロットする（図 2).

(iii）参入の境界については，プロット全体の下限をつないでいくことで導出する（ただし，シミュレー ションによって生じた明らかに状況に適していないプロットは除く.(iv) についても同様である.).

(iv) 撤退の境界については，プロット全体の上限をつないでいくことで導出する（図 $3,4 ）$.

最後に, シミュレーションによる時点 $t$ でのプロジェクトの価值の導出法を説明する。 ここで時点 $t$ で

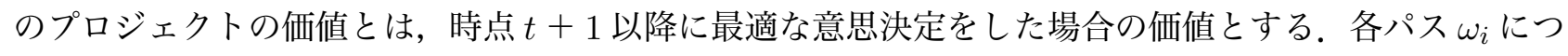




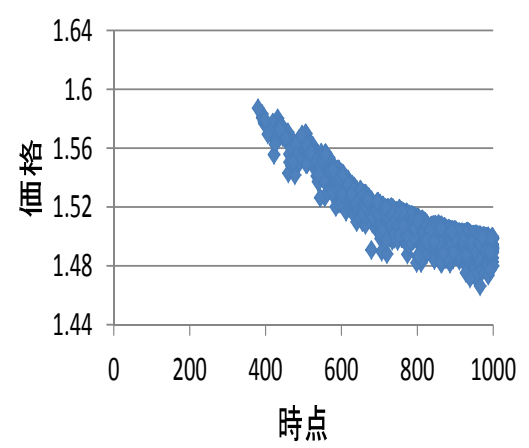

図 2: 撤退のプロット例

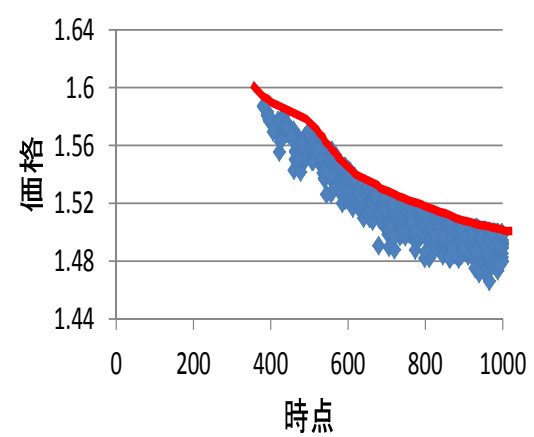

困 3: 撤退の境界を求める例

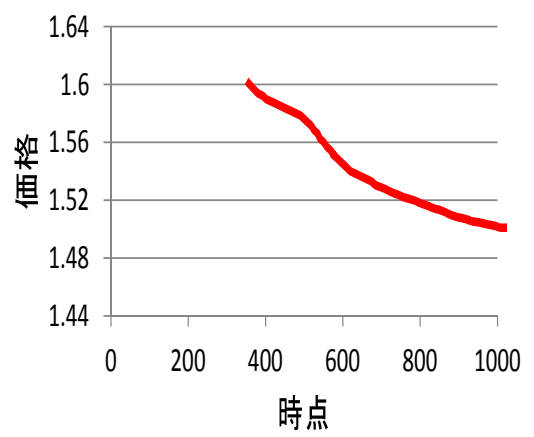

困 4: 撤退の境界例

いて, 時点 $t$ でステージ $j$ にいる価值を $V_{B}\left(P_{t}\left(\omega_{i}\right), j\right)$ とする. 各時点 $t$ での価值の平均をとることで時 点 $t$ でのプロジェクトの価值 $\bar{V}(t)$ を求めるとすると, $\bar{V}(t)$ は

$$
\bar{V}(t)=\frac{\sum_{i=1}^{L}\left(V_{B}\left(P_{t}\left(\omega_{i}\right), j\right)\right)}{L}, \quad(j=0,1),
$$

と書ける。ここで, $\bar{V}(t)$ は時点 0 から見た時点 $t$ でのプロジェクトの価值の期待值を意味する. したがつ て，全時点で $\bar{V}(t)$ を求めることでプロジェクトの価值の時間変化を導出できる.

\section{3 数値実験}

本節では 2 節で示したモデルを用いた数值実験を行う。数值実験を行う際，平均回帰過程の特徵から 参入と撤退の可能性や境界は価格の初期值と長期平均に大きく依存する。なぜなら, 無限期間では価格 は定常状態であると考えられるが，有限期間では同様には考えられないからである，そのため，有限期 間の場合, 価格が定常状態に至るまでの部分も重要であり, 無限期間と異なる結果を示す要因になる. 本研究では, 初期価格 $P_{0}$ と長期平均 $\theta$ により, プロジェクトに 4 種類の特徵が確認されたため, $P_{0}$ と 長期平均 $\theta$ に関して特徵を示す以下の 4 パターンを考える.

1. $P_{0}=1.5, \theta=3$

2. $P_{0}=2.5, \theta=1$

3. $P_{0}=1.8, \theta=2.3$

4. $P_{0}=2, \theta=1.5$

(以下，パターン 1 , パターン 2 , パターン 3 , パターン 4 と記す.)

各パターンにおいて, 最初にプロジェクトの期間の長さがプロジェクトの価值に与える影響を示す. 期間が長くなるにつれて，プロジェクトの価值が高くなることは想像に難くないが，グラフを用いて確 認する. 次に, $\kappa$ との值による, 参入と撤退の頻度について検証する. 頻度を見ることで, 各パター ンにおいて参入や撤退の起こりやすさを知ることにつながり，分析対象を明確にすることができる．最 後に, (1) 式のパラメータ $\kappa, \sigma$ が参入と撤退のタイミングに与える影響を明らかにすると同時に, 平均 回帰過程と幾何ブラウン運動 $(\kappa=0)$ の比較を行う。 3.1 節, 3.2 節, 3.3 節, 3.4 節では各パターンでの プロジェクトの価值，参入と撤退の頻度と参入または撤退の境界の形状を示し，各パラメータがそれら 


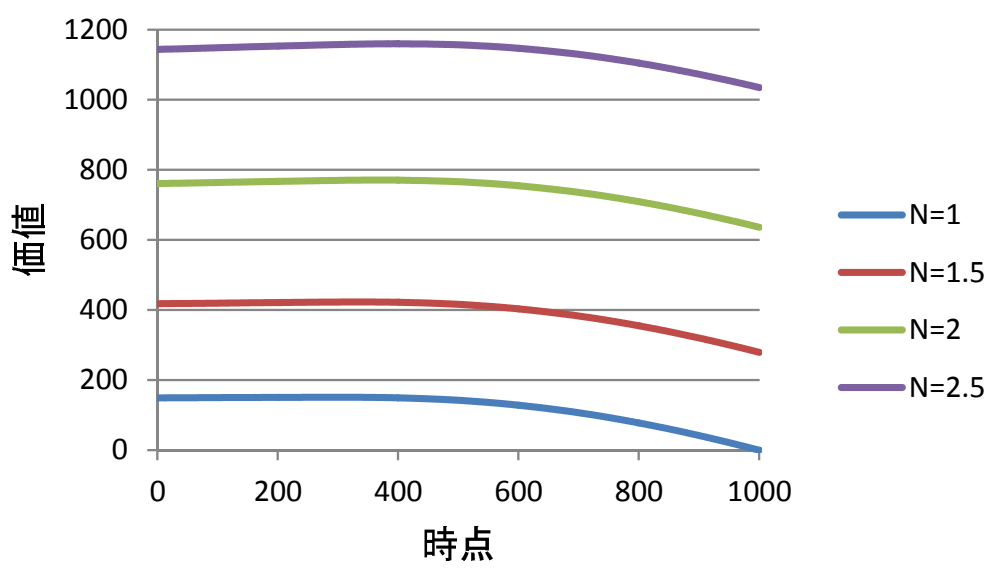

図 5: パターン 1 における満期が異なる場合のプロジェクト価值の時間変化 $(\kappa=1, \sigma=0.15)$

に与える影響を考察する。本節で行う数值実験では，プロジェクトの期間を $N$ 年，モンテカルロシミュ レーションによる価格パス数 $L$ は 50,000 本, 期待值計算の近似関数の次数は 15 , 安全利子率 $r=0.04$, 撤退コスト $K_{0}=2$, 参入コスト $K_{1}=3$, 生産コスト $c=2$ とし, 2 節同様に 1 年間では企業は 1,000 回 の意思決定のタイミングの機会があるとして実験を行う.

\section{1 パターン $1\left(P_{0}=1.5, \theta=3\right)$}

本節では $P_{0}=1.5, \theta=3$ であるパターン 1 の分析を行う。まずは期間が長くなるに連れて。プロジェ クトの価值がどのように変化するのかを図 5 に示す。図 5 は期間が異なる場合のプロジェクトの価值の 時間変化を表している。この図は，まず $L$ 本のパスを一番長い期間 $(N=2.5)$ の最終時点まで発生さ せ，同じパスを用いて期間が異なる場合の価值を $N=1$ に合わせ 1,000 時点までプロットしたものであ る。この場合では初期価格と長期平均の関係より価格が大きく上昇することから，多くの場合，企業は 参入状態で満期を迎える。図 5 より，Nが大きくなるほど各時点の価值も高くなることが読み取れる. パターン 1 ではプロジェクトの期間が長いほど将来の期待キャッシュフローが大きくなるので，プロジェ クトの期間が短い場合より，プロジェクトの価值も大きくなる。すなわち，有限期間の問題を無限期間 を仮定したモデルで分析すると, 商品の価格は同じであるにもかかわらずプロジェクトの価值を過大評 価することになる。 またグラフの形状として $N=1$ から $N=2.5$ の全てで, 価值が一定に近い状態か ら，その後下がっていく様子が分かる。これは，一般的に満期時点に近づくにつれて価值が下がってい くことは当然であるが，価格が上昇傾向を持つパターン 1 では定常状態に至るまで価值の増加が期待さ れるためであると考えられる。したがって, 全ての期間において, 同じ時点で価值が右下がりになると 言える。結果として, 価值の大きさは期間に依存しているので, 無限期間のモデルを有限期間の問題に 用いると大きな誤差が生じる。

次に, 参入と撤退の頻度について図 6 に示す。図 6 はパターン 1 における各パラメータの参入と撤退 の頻度を表している．図 6 より，各パラメータでほぼ全てのパスが参入するが，撤退は起きにくいこと が分かる．価格が高い值で保持されるので撤退しないことは妥当である．したがって，パターン 1 では 参入の境界についてのみ議論する.

最後に, 参入の境界について考察する. 参入の境界について図 7 に $\kappa$ が, 図 8 に $\sigma$ が境界に与える影 


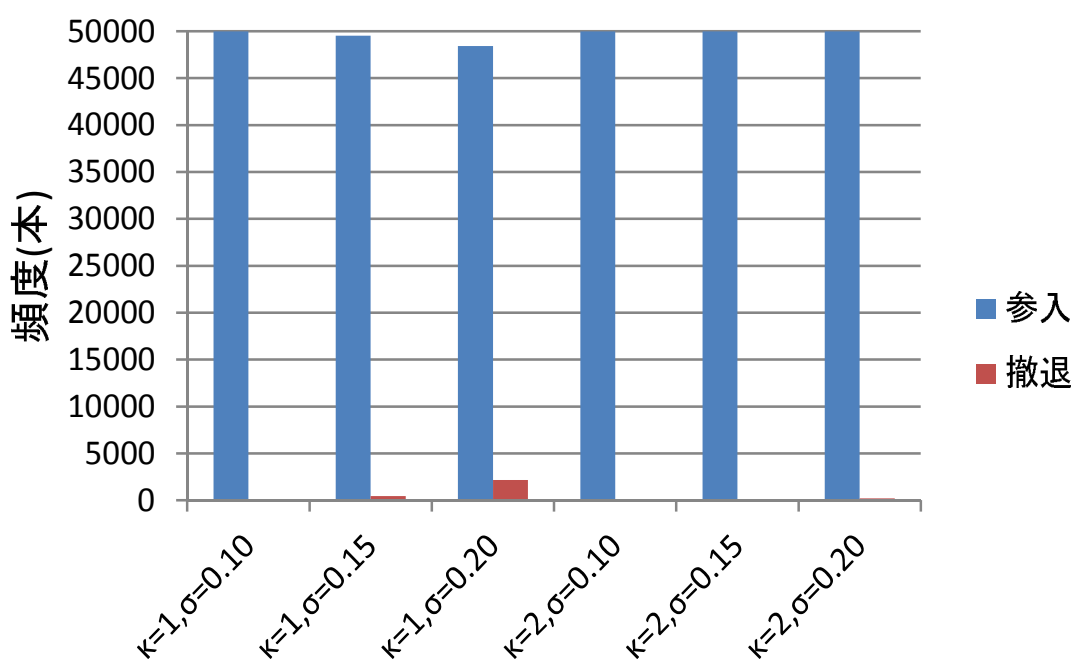

図 6: パターン 1 における各パラメータの参入と撤退の頻度

響を示す. 図 7 はパターン 1 における $\kappa$ が異なる場合の参入の境界の時間変化, 図 8 はパターン 1 にお ける $\sigma$ が異なる場合の参入の境界の時間変化を表している. 図 7,8 の閾值がない部分は，参入が起こら

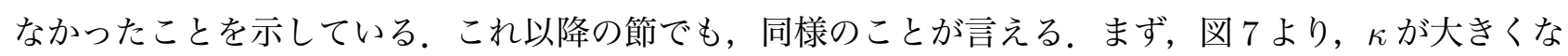
ると参入の境界は低くなることが分かる。もし価格が低い場合でも, 将来のキャッシュフローが大きい

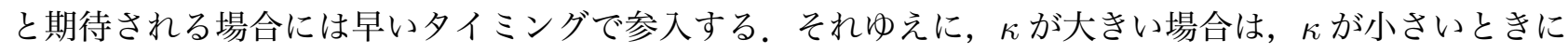
比べ価格が低い状況でも参入が起こる。 また境界の形状に関しては， $\kappa=1, \kappa=2$ の場合では初期時点 の近くでは右上がりであり，その後は水平になっている。これは時点が早いときは価格の上昇傾向が強 いので価格が低いときでも参入し，時点が進むにつれて価格が長期平均に近づくことで参入する值は一 定に近いものになる。 さらに， $\kappa=1$ で満期時点付近では再度右上がりになるが，満期時点付近に参入 することにより参入コストを回収することが難しくなるからだと考えられる. 次に, $\kappa=0$, つまり平均 回帰性を持たない場合には，形状は水平になることはなく右上がりを続けることが読み取れる．価格が ある值に収束しないので，残り期間が短くなるほど得られるキャッシュフローが小さくなり，参入する 条件が厳しくなるからであると言える。したがって，パターン 1 においては， $\kappa$ の増加は参入価格を下 げ，境界を一定にすることにつながり参入しやすい状況を作る．無限期間のモデルでは境界が一定の值 として算出されるので， $\kappa$ が小さいときに無限期間のモデルを有限期間の問題に適用することは大きな 誤差を生むことになる. 次に, 図 8 より $\sigma$ が参入の夕イミングに与える影響を考察する. 図 8 から $\sigma$ に よる形状の大きな変化は見られないが， $\sigma$ が小さくなるにつれて，参入の境界が下がり参入しやすい状 態になることが分かる．価格が上昇する状況のときに $\sigma$ が大きいことは，上昇傾向を抑えてしまうこと になる，よって，参入しづらいことになるので，境界が上がることになる，パターン 1 のように価格が 大きく上がる場合には $\sigma$ が小さいほど参入が起こりやすい境界であると言える. 


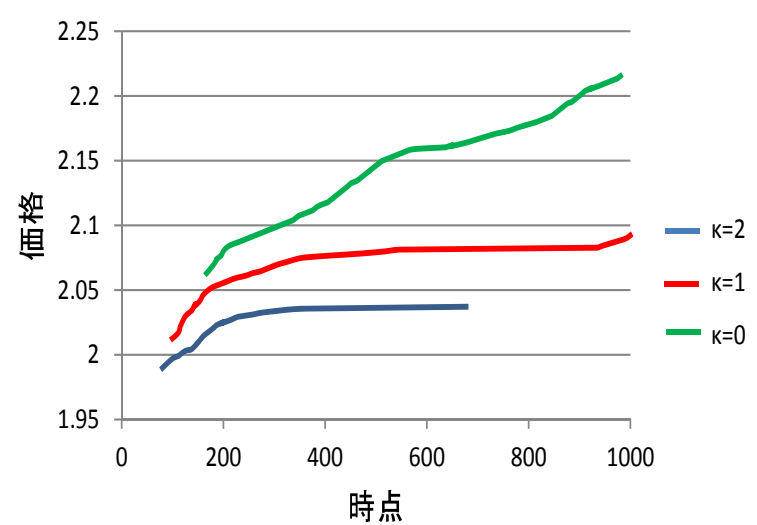

図 7: パターン 1 における $\kappa$ が異なる場合の参 入の境界の時間変化 $(\sigma=0.20, N=1)$

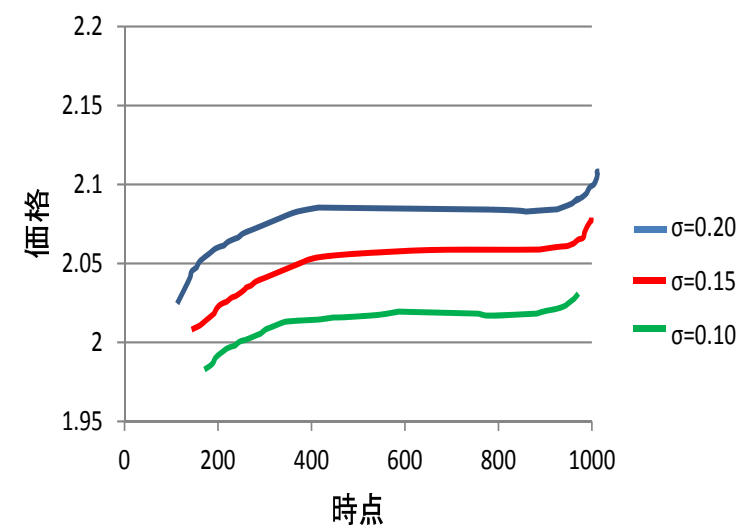

図 8: パターン 1 における $\sigma$ が異なる場合の参 入の境界の時間変化 $(\kappa=1, N=1)$

\section{2 パターン $2\left(P_{0}=2.5, \theta=1.0\right)$}

本節では $P_{0}=2.5, \theta=1.0$ のパターン 2 の分析を行う。まずは前節同様，期間が長くなるに連れてプ ロジェクトの価值がどのように変化するのかを図 9 に示す。図 9 は期間が異なる場合のプロジェクト価 值の時間変化を表している。 この図もパターン 1 と同様に, 同じパスを用いて期間が異なる場合の価值 を 1,000 時点までプロットしグラフ化したものである. 図 9 からはパターン 2 でも $N$ が大きくなるほど 各時点での価值が高くなることが読み取れるだけでなく, 撤退することにより収束していく様子も見る ことができる。したがって，プロジェクトの期間が十分に長ければ無限期間のモデルを適用できる可能 性はあるが，過大評価を避けるためにも有限期間の問題として分析すべきだと言える. 時間変化の様子 については $N=1$ から $N=2.5$ の全てで, 価值が右下がりになっている.これは, まず初期時点付近で

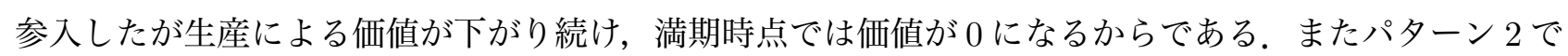
は, 時点が進むことで価格は低くなる。したがって, プロジェクトの期間が長くなったとしても, 生産 コストを下回るような価格では参入状態を継続し生産することは起こらない. よって, 期間を長くする につれて価值が収束していく結果になる。結論として，プロジェクトの価值が収束しないような期間が 短いときに無限期間のモデルを有限期間の問題に用いる場合には注意が必要である.

次に，参入と撤退の頻度について図 10 に示す。図 10 はパ夕ーン 2 における各パラメータの参入と撤 退の頻度を表している，図 10 よ，各パラメータで全てのパスが参入し，そのほとんどが撤退すること が分かる．初期価格が高い值に設定されているので参入することは当然であり, 長期平均が小さいので 結果として撤退することも妥当である。しかし，初期価格の值によりプロジェクト開始と同時に参入が 起こることが大多数であるので，参入の境界は議論に值せず撤退の境界についてのみ議論する.

最後に，撤退の境界について考察する。撤退の境界について図 11 に $\kappa$ が，図 12 に $\sigma$ が境界に与える 影響を示す。図 11 はパターン 2 における $\kappa$ が異なる場合の撤退の境界の時間変化, 図 12 はパターン 2 における $\sigma$ が異なる場合の撤退の境界の時間変化を表している. 図 11 より， $\kappa$ が小さくなると撤退の境 界が下がっていくことが読み取れる。もし価格が高い状況でも, 将来のキャッシュフローが小さく見積

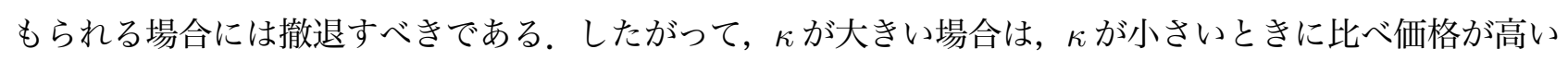
にもかかわらず撤退を決める。このため， $\kappa=2$ の境界では撤退する時点が早く，撤退する価格が高く

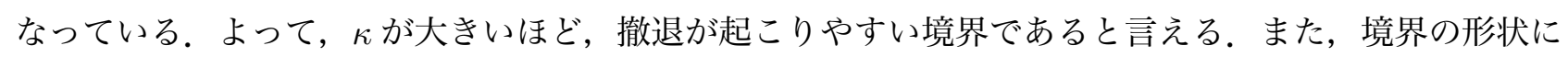




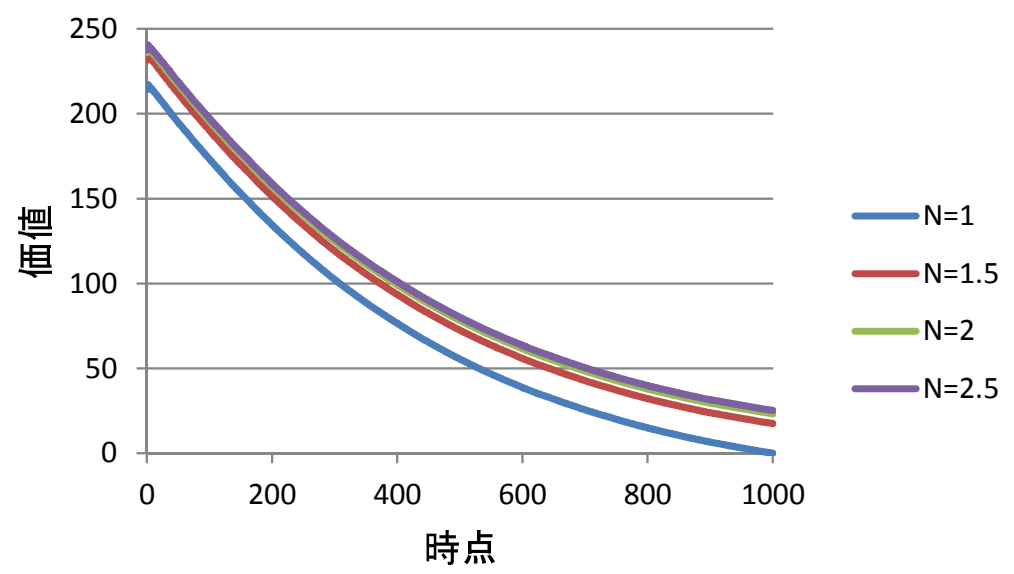

図 9: パターン 2 における満期が異なる場合のプロジェクト価值の時間変化 $(\kappa=0.5, \sigma=0.15)$

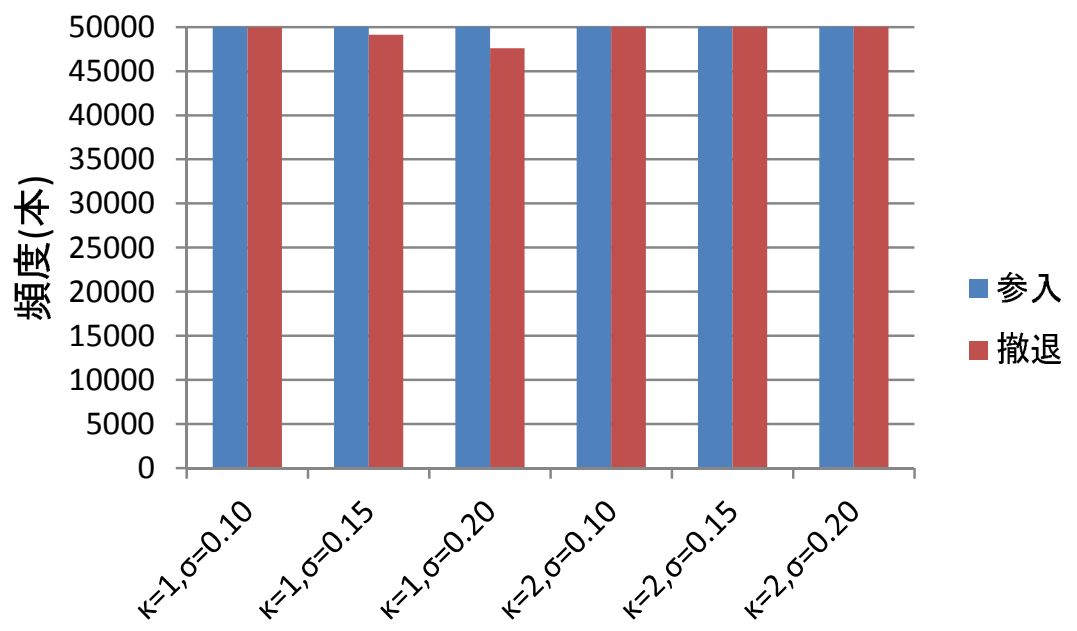

図 10: パターン 2 における各パラメータの参入と撤退の頻度 


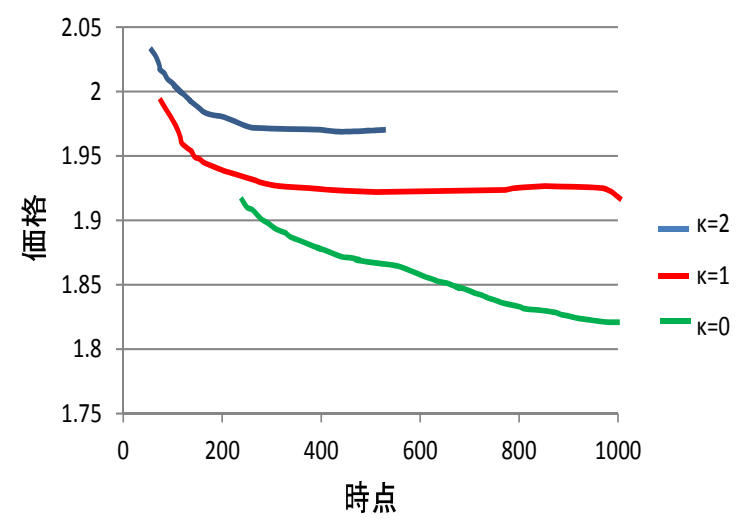

図 11: パターン 2 における $\kappa$ が異なる場合の 撤退の境界の時間変化 $(\sigma=0.15, N=1)$

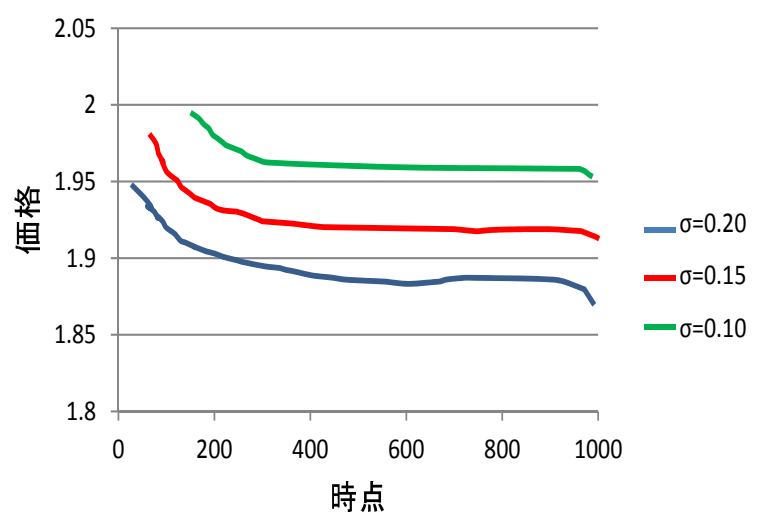

図 12: パターン 2 における $\sigma$ が異なる場合の 撤退の境界の時間変化 $(\kappa=1, N=1)$

関しては, $\kappa=2$ と $\kappa=1$ では初期時点付近から一旦下がり，その後は一定の值を取るようになる。た

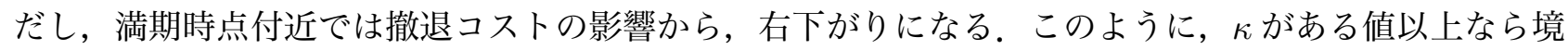
界が一定の值になるが，平均回帰性を持たない $\kappa=0$ では初期時点から境界は右下がりのままである. $\kappa=0$ では長期平均に近づくということがないので, 撤退の条件は時点が進むにつれて厳しくなり続け る。したがって, $\kappa$ が小さいときには境界が一定にならないことより, 無限期間のモデルを適用するこ とは避けるべきである，次に，図 12 より $\sigma$ が撤退の夕イミングに与える影響を考察する。図 12 から $\sigma$ による形状の大きな変化は見られないが， $\sigma$ が小さくなるにつれて，撤退の境界が上がり撤退しやすい 状態になることが分かる．価格が下降する状況のときに $\sigma$ が大きいことは，下降傾向を弱めてしまうこ とにつながる，よって，撤退が起こりにくくなるので，境界が下がることになる，パターン 2 のように 価格が大きく下がる場合には $\sigma$ が小さいほど撤退が起こりやすい境界となる.

\section{3 パターン $3\left(P_{0}=1.8, \theta=2.3\right)$}

本節では $P_{0}=1.8, \theta=2.3$ であるパターン 3 の分析を行う。まずは本節でも期間が長くなるに連れて. プロジェクトの価值がどのように変化するのかを図 13 に示す。図 13 はパターン 3 における期間が異な る場合のプロジェクト価值の時間変化を表している．図 13 からはパターン 1 ほどではないが，プロジェ クトの期間が長くなるにつれてに各時点の価值が高くなることが分かる。 パターン 1 に比べ, 初期価格 からの上昇幅が小さいので期間による価值の差は小さくなる，さらに，定常状態に早い時点で至るので， 価值が一定の期間が短くなる様子も読み取れる。しかし，パターン 3 の場合でも依然として期間が長い ときにプロジェクト価值が高いことは変わらず，無限期間を仮定したモデルで分析すると，プロジェク トの価值を過大評価することになる。したがって，パターン 3 においても無限期間と有限期間を分けて 議論する意味はある.

次に，参入と撤退の頻度について図 14 に示す。図 14 はパターン 3 における各パラメータの参入と撤 退の頻度を表している。図 14 より， $\sigma$ が大きいほど参入の頻度は下がり，撤退の頻度は上がることが分 かる．初期価格と長期平均の関係から，参入の頻度が高くなるが，時点が進むことで参入していくので 参入の境界について議論することが可能である。 また, パターン 1 とは違い撤退が起こる状況であるこ とから, 撤退の境界についても考察する. 


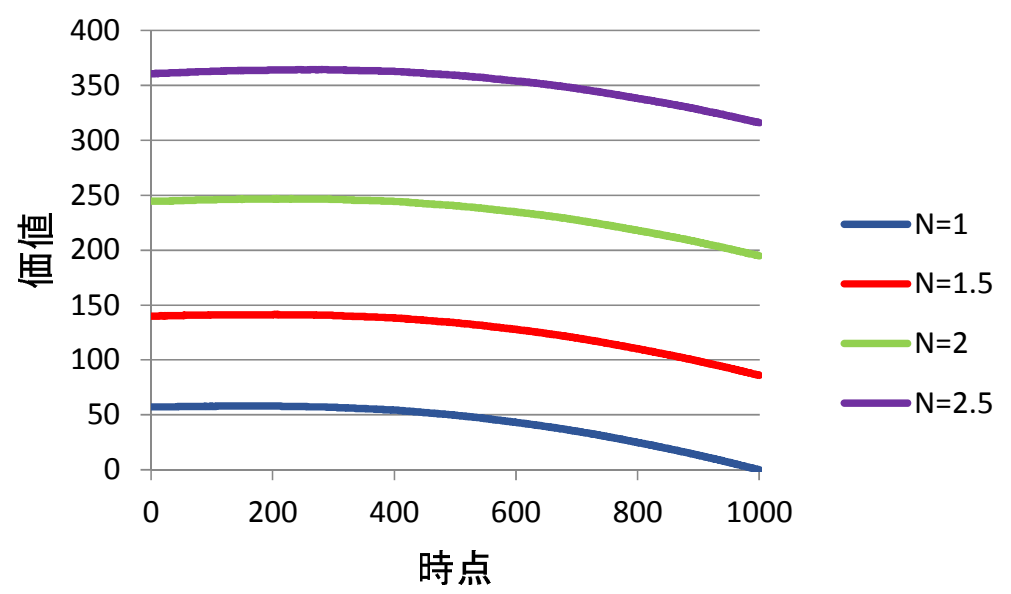

図 13: パターン 3 における期間が異なる場合のプロジェクト価值の時間変化 $(\kappa=1, \sigma=0.15)$

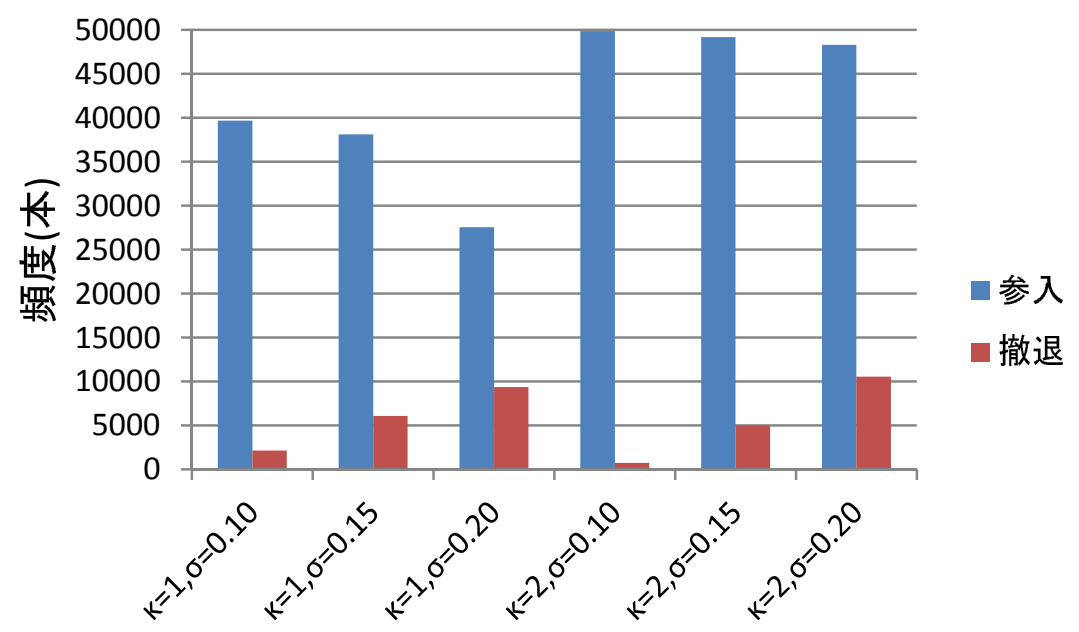

図 14: パターン 3 における各パラメータの参入と撤退の頻度 


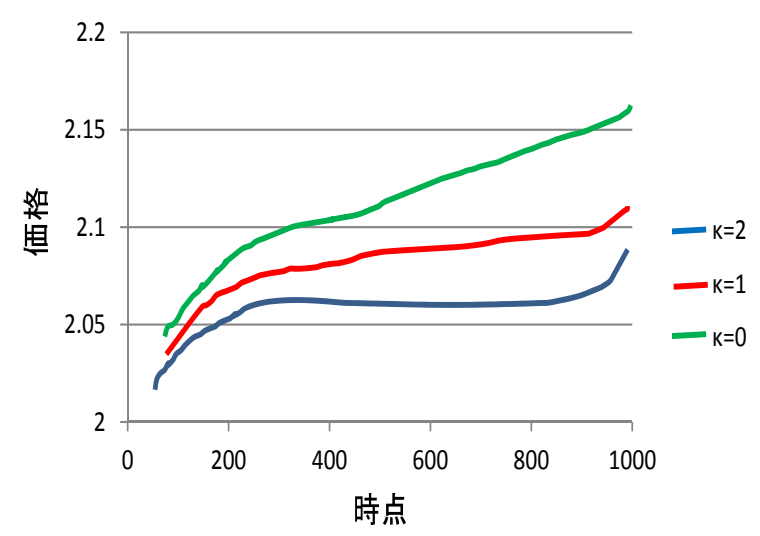

図 15 : パターン 3 における $\kappa$ が異なる場合の 参入の境界の時間変化 $(\sigma=0.15, N=1)$

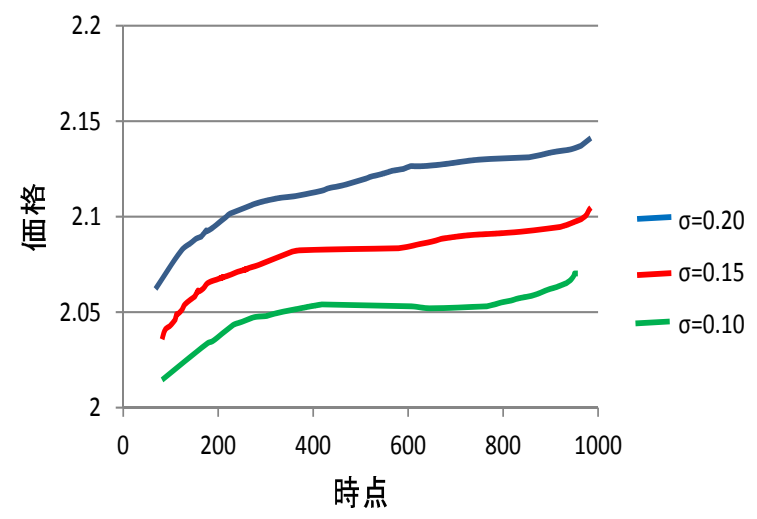

図 16: パターン 3 における $\sigma$ が異なる場合の 参入の境界の時間変化 $(\kappa=1, N=1)$

最後に，参入と撤退の境界について考察する. 第 1 に参入の境界について図 15 にが，図 16 に $\sigma$ が 境界に与える影響を示す。図 15 はパターン 3 における $\kappa$ が異なる場合の参入の境界の時間変化, 図 16 はパターン 3 における $\sigma$ が異なる場合の参入の境界の時間変化を表している. 図 15 より $に$ にる参入夕

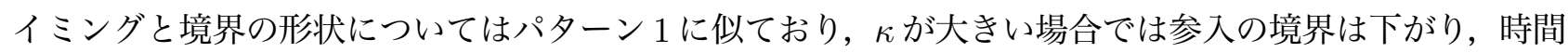
が経つにつれて境界の值は一定になることが分かる。 パターン 3 ではパターン 1 より初期価格と長期平 均の差が小さいことから， $\kappa=2$ においても満期時点付近で再び境界が上がり参入が起こりにくくなる. さらに，平均回㷌性を持たない $\kappa=0$ では，境界は右上がりであり平均回帰過程との参入夕イミングの 違いが読み取れる。 また, 図 16 より, パターン 1 と同様に $\sigma$ が小さいときほど境界が下にあり参入が起 こりやすい状態である様子が見て取れる. 形状については $\sigma=0.10, \sigma=0.15$ のさは，初期時点付近 で一旦上がってから一定值を取るようになり, 最終時点付近で再度上がるような形状をしている，しか し， $\sigma=0.20$ を見て分かるように， $\sigma$ が大きいと右上がりを続けるようになる．したがって， $\sigma に よ り ，$ 時点が進むほど参入の境界の差が大きくなると言える，結果として 2 つ図から言えることは，パター ン 3 では, 参入の境界について $\kappa$ の減少と $\sigma$ の増加は似た働きをする, ということである. よって, 参 入の境界が時間によらず一定となる無限期間のモデルを $\kappa$ の值が小さい場合や $\sigma$ の值が大きい場合に適 用すべきでない.

第 2 に，撤退の境界について考察する．図 17 に $\kappa$ が，図 18 に $\sigma$ が境界に与える影響を示す．図 17 は パターン 3 における $\kappa$ が異なる場合の撤退の境界の時間変化, 図 18 はパターン 3 における $\sigma$ が異なる

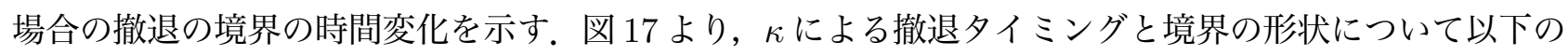

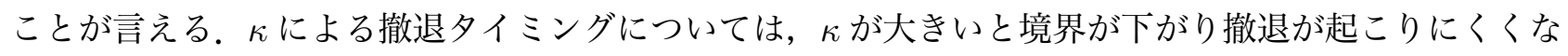
るだけではなく， $\kappa=0$ の場合と境界が交差している。境界の形状については, 満期時点付近では一定

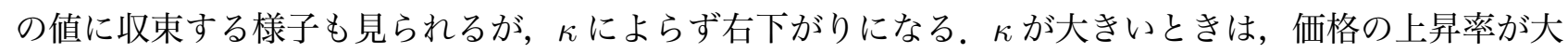
きくなるので撤退が起きにくくなり, 撤退時の価格が低くなる. さらに, 平均回帰性を持たない場合に 比べ時点が早い段階では, 撤退が起きにくいことから撤退時の価格は低いが, 時点が進むと右下がりの 傾向が弱くなり，右下がりのままである $\kappa=0$ と境界は交わる。また図 18 より， $\sigma$ に関する境界の変化 についても，境界は右下がりであることが読み取れる。確かに $\sigma$ がどの值でも右下がりの形状を持つが, $\sigma$ が小さいほど右下がりの傾向は弱くなり, 時点が進むと各 $\sigma$ による撤退時の価格に差が生じる可能性 がある，結果として 2 つ図から，撤退の境界は右下がりであるが，特に $\kappa$ が小さい場合と $\sigma$ が大きい 


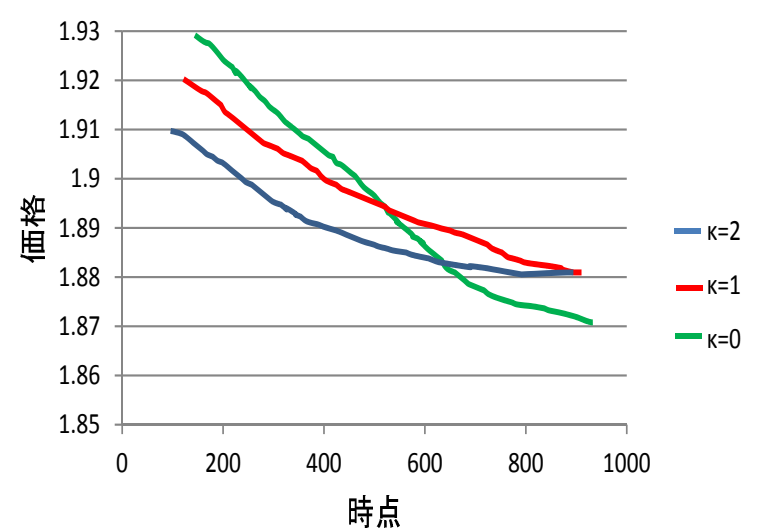

図 17: パターン 3 における $\kappa$ が異なる場合の 撤退の境界の時間変化 $(\sigma=0.15, N=1)$

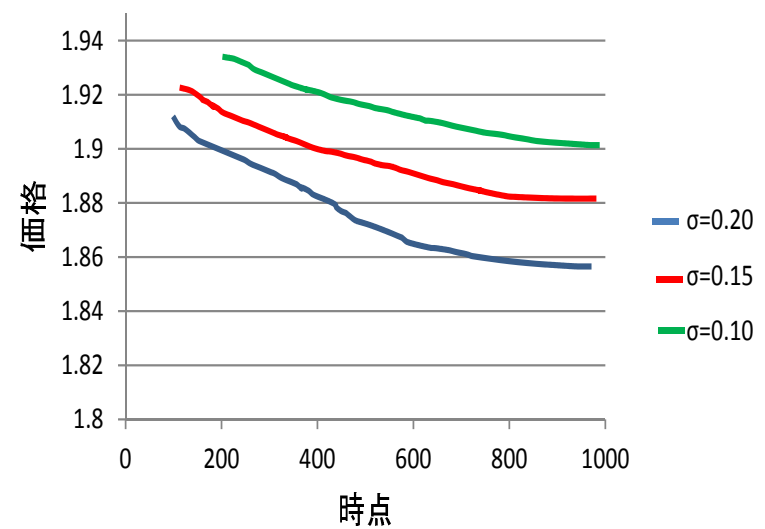

図 18: パターン 3 における $\sigma$ が異なる場合の 撤退の境界の時間変化 $(\kappa=1, N=1)$

場合にはその傾向が強くなり，無限期間のモデルを適用する場合には注意が必要である.

\section{4 パターン $4\left(P_{0}=2.0, \theta=1.5\right)$}

本節では $P_{0}=2.0, \theta=1.5$ であるパターン 4 の分析を行う。まずは期間が長くなるに連れて。プロ ジェクトの価值がどのように変化するのかを図 19 に示す。図 19 はパターン 4 における期間が異なる場 合のプロジェクト価值の時間変化を表している，他のパターンと同様に，図 19 からも，プロジェクト の期間が長いときに各時点の価值が高くなることが見て取れる。グラフの形状としてはパターン 1 とパ ターン 2 の中間のような形状をしており, 初期時点から価值が高い状態が少し続き, 減少していく様子 を表している。 また，パターン 4 でも期間を長くするにつれてプロジェクトの価值が収束していくこと が分かる．初期時点付近では，参入し生産することで価值が生まれる場合があるが，時点が進むにつれ て価格が下がることにより，プロジェクトの価值は減少していく．さらに，パターン 2 のときのように， 期間を長くしても商品を生産することによる利益が明らかに増えるわけではないので，価値は収束して いくことになる。したがって，期間が長くなるにつれてプロジェクトの価值の差は小さくなるが，期間 が長いほど価值は大きいのでパターン 4 においても無限期間のモデルを有限期間のプロジェクトに用い るときは注意しなければならない.

次に, 参入と撤退の頻度について図 20 に示す。図 20 はパターン 4 における各パラメータの参入と撤

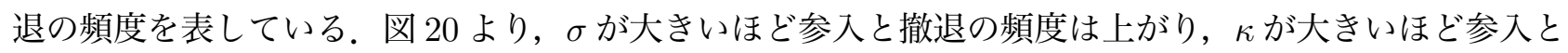
撤退の頻度は下がることが分かる．初期価格と長期平均の関係から，参入後に撤退することが多くなる ことは考えやすい. しかし, パターン 2 のように初期時点付近でのみ参入が起こるわけではないので, 参入と撤退の両方の境界について議論する.

最後に，参入と撤退の境界について考察する。第 1 に参入の境界について図 21 にが，図 22 にが 境界に与える影響を示す。図 21 はパターン 4 における $\kappa$ が異なる場合の参入の境界の時間変化, 図 22 はパターン 4 における $\sigma$ が異なる場合の参入の境界の時間変化を表している. 図 21 より, パターン 1 や パターン 3 とは異なる参入の境界を持つことが分かる。まず平均回帰性を持つ場合に，時点が進むにつ れて参入時の価格が上がり, その後一定になることは変わらないが， $\kappa=1$ と $\kappa=2$ で近い值に収束し ている.さらに， $\kappa$ にり参入時の価格が単純に上がるだけでなく, 時点 600 付近で $\kappa=0$ と交差して 


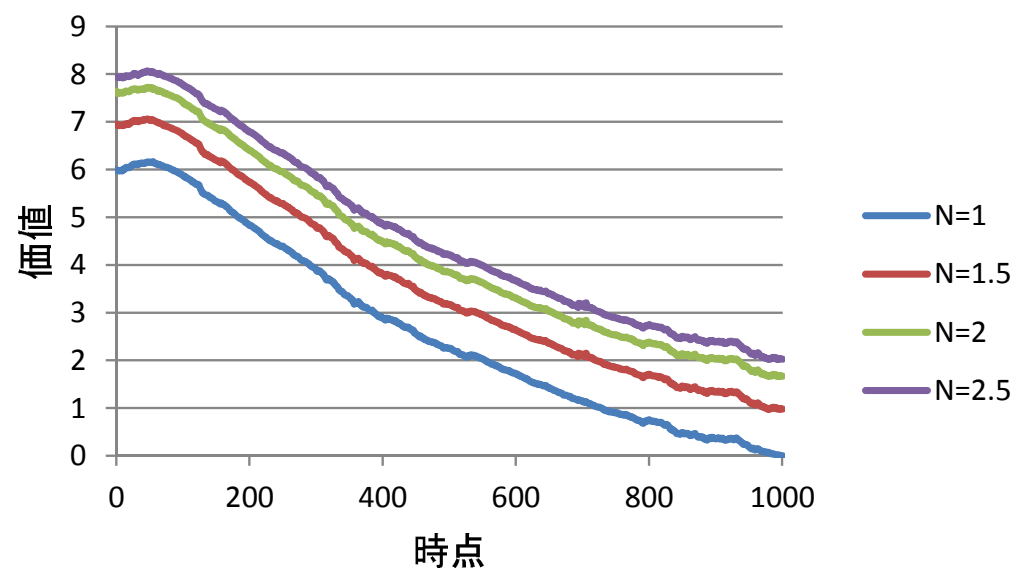

図 19: パターン 4 における期間が異なる場合のプロジェクト価值の時間変化 $(\kappa=1, \sigma=0.15)$

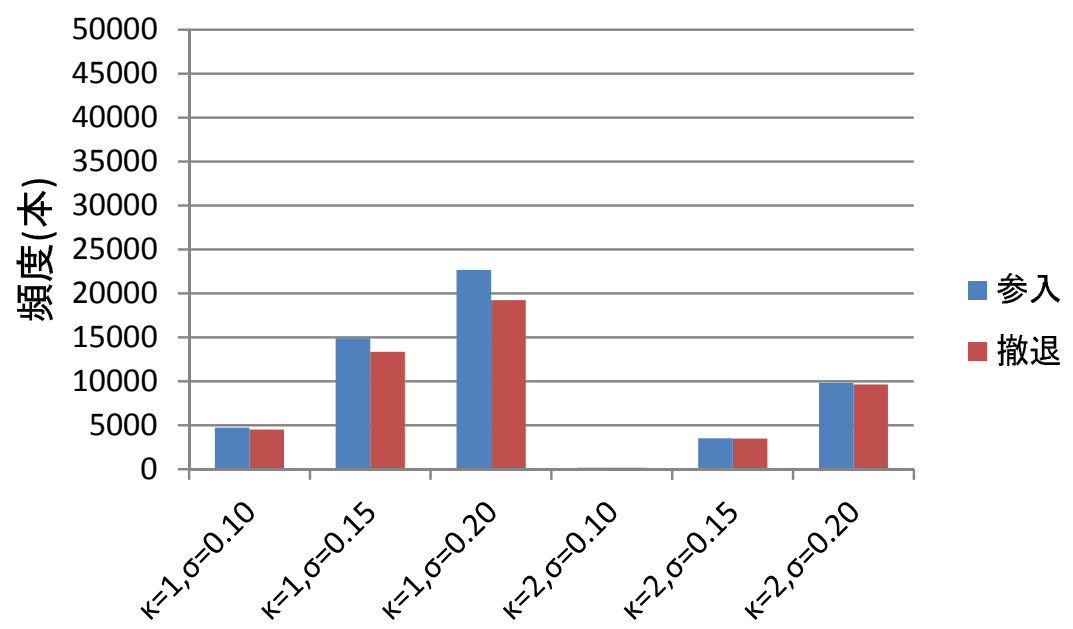

図 20: パターン 4 における各パラメータの参入と撤退の頻度 


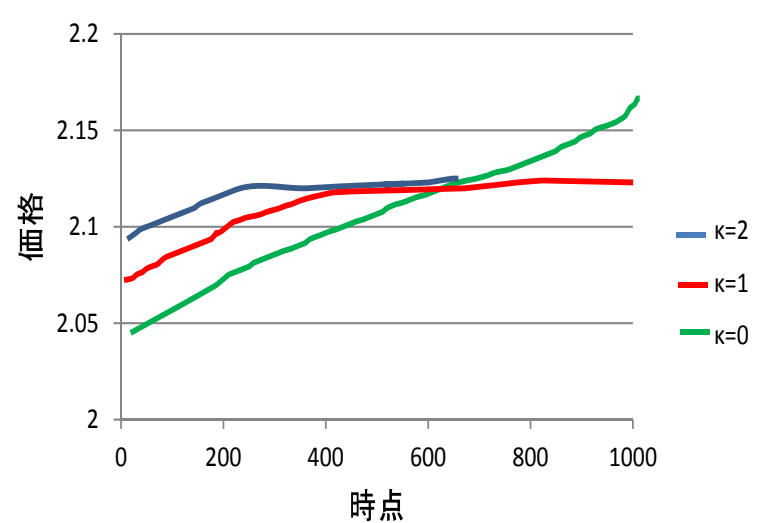

図 21: パターン 4 における $\kappa$ が異なる場合の 参入の境界の時間変化 $(\sigma=0.15, N=1)$

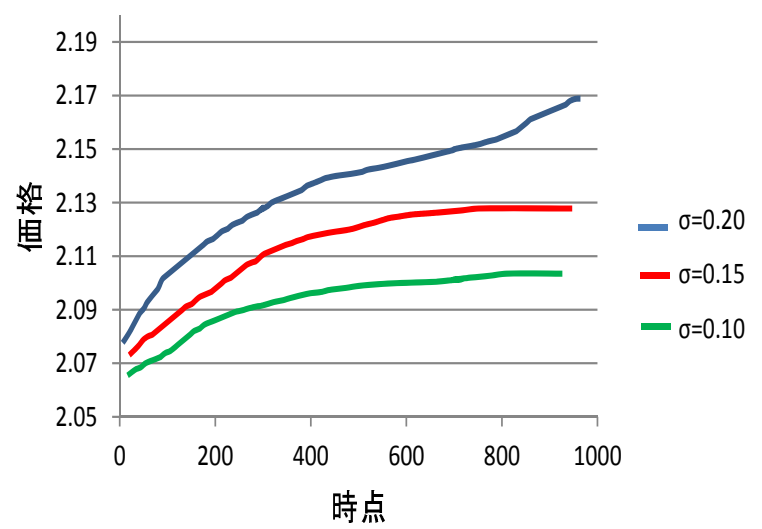

図 22 : パターン 4 における $\sigma$ が異なる場合の 参入の境界の時間変化 $(\kappa=1, N=1)$

いる. パターン 4 では価格が下降傾向を持つので， $\kappa$ が大きいときは参入しにくいため参入時の価格は 高くなる。しかし，平均回帰性を持たない場合には，境界は右上がりを続けるため，ある值に収束する 平均回帰性を持つ境界と交差することになる。したがつて，平均回帰性を持つときと持たないときでは， 参入の境界の振る舞いが大きく異なると言える。また，図 22 より $\sigma=0.10, \sigma=0.15$ の場合は参入の境 界が右上がりから平行になる様子が見られるが， $\sigma=0.20$ では右上がりのままであることが分かる．初 期価格と長期平均の差が小さい状況では， $\sigma$ が大きいと平均回帰性を妨げてしまうことにより，右上が りを続けると考えられる。図 21 と図 22 から，パターン 4 では参入の境界の形状について， $\kappa$ と $\sigma$ は逆 の働きをしており，無限期間のモデルを適用する場合は両方のパラメータに注意する必要がある.

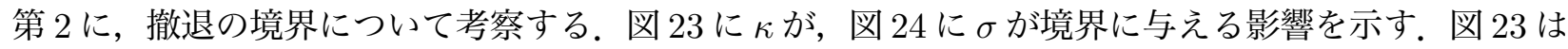
パターン 4 における $\kappa$ が異なる場合の撤退の境界の時間変化, 図 24 はパ夕ーン 4 における $\sigma$ が異なる場 合の撤退の境界の時間変化を示す，図 23 より $\kappa$ が大きいときは撤退時の価格が高く, 境界の形状が平行

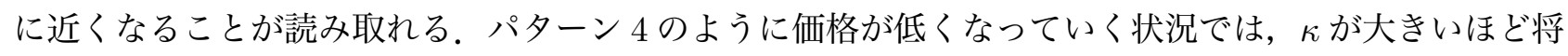
来得られるキャッシュフローが小さくなるので, 早めに撤退しょうと考えるので撤退時の価格が高くな る. 逆に, $\kappa$ が小さいほど, 早期撤退のインセンティブは生まれなくなり, 平均回帰性を持たない $\kappa=0$ のように右下がりの境界になっていく．したがって，パターン 4 についても平均回帰性を持つ場合と持 たない場合では，撤退夕イミングが異なるという結果になる。また図 24 より， $\sigma$ が小さい場合ほど撤退

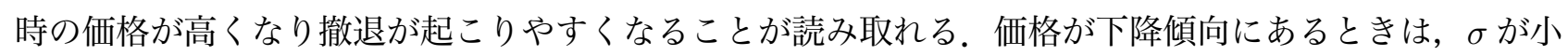
さく平均回帰性の影響を強く受けることにより撤退しやすくなることから，撤退時の価格が上がる．加 えて $\sigma=0.15$ と $\sigma=0.20$ を見ると, 初期時点付近では撤退時の価格の差は小さいが，徐々に差が広が ることも分かる。 よって， $\sigma$ が大きいほど，撤退が起こりにくい境界を持つ。よって，図 23,24 から撤 退の境界についても $\kappa$ が小さい場合や $\sigma$ が大きい場合には，無限期間のモデルを適用することは特に好 ましくないと言える。 


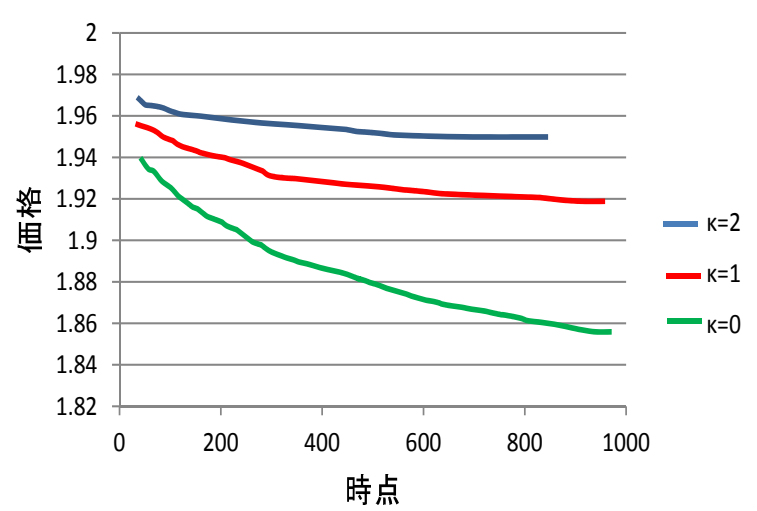

図 23: パターン 4 における $\kappa$ が異なる場合の 撤退の境界の時間変化 $(\sigma=0.15, N=1)$

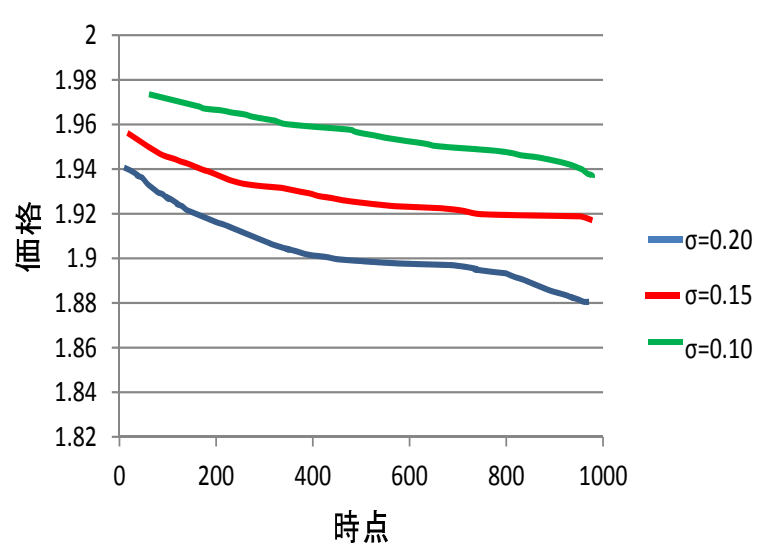

図 24: パターン 4 における $\sigma$ が異なる場合の 撤退の境界の時間変化 $(\kappa=1, N=1)$

\section{4 結論}

本研究では，有限期間における企業の投資夕イミングの分析を行うモデルを構築した。そしてモデル による数值実験から，次の 2 点を示した。第 1 に，期間が有限のプロジェクトに対して無限期間のモデ ルを用いるのではなく，有限期間のモデルで分析することの有用性を明らかにした，平均回帰過程の下 でのパターン分析から，全てで期間が長くなるほどプロジェクトの価值が上がるため，無限期間のモデ ルを使用することはプロジェクトの過大評価につながる。したがつて, Tsekrekos [7]で議論されている 無限期間のモデルを有限期間の問題に適用する場合には過大評価になりがちであることに注意が必要で ある. 第 2 に，平均回帰性が企業の投資夕イミングに与える影響と，平均回帰過程と幾何ブラウン運動

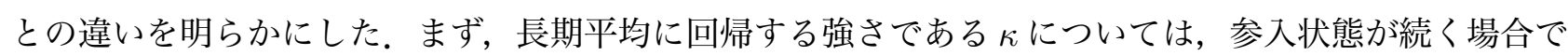
は $\kappa$ が大きくなるほど参入の決定を早める。 また，参入後に撤退する頻度が高い場合では $\kappa$ が大きくな るほど撤退の決定を早める。さらに，参入と撤退の境界は平均回帰過程と幾何ブラウン運動の場合で大 きく異なることも確認でき，平均回帰性を持つときはある值に収束していく場合があるが，幾何ブラウ ン運動では単調な変化となる。また，確率項のボラティリティである $\sigma$ は值が小さいときに参入と撤退 が起こりやすい境界を持つ. 結果として, 参入と撤退の夕イミングに関して, 平均回帰過程と幾何ブラ ウン運動との違い, さらには無限期間では考慮されていない定常状態に至る過程の分析を可能にした.

今後の課題としては, 以下の 2 点がある. 第 1 に, 本研究のモデルは平均回帰過程の場合以外でも分 析することが可能であるので, 解析的なアプローチが難しい他の確率過程に従う問題を考えることであ る. 第 2 に, 平均回帰過程に従うとされる実データを用いて企業の投資夕イミングの評価を行うことで ある.

\section{A＼cjkstart意思決定が与える影響について}

本研究では連続型のモデル構築を目標としており，1 年間において 1,000 回の意思決定をできるとし たならば，連続的な意思決定が十分に近似可能であると考えた，その理由として，意思決定を 1,000 回 とすれば，それより意思決定の回数を多くした場合の価值との差は非常に小さいことを数值実験で確認 した。表 1 は， 3 節のプロジェクトの価值の算出に用いたパラメータにおいて，各パターンと各意思決 
表 1: 各パターンと各意思決定回数におけるプロジェクト価値の変化率

\begin{tabular}{|c|c|c|c|c|c|}
\hline & & パターン 1 & パターン 2 & パターン 3 & パターン 4 \\
\hline \multirow{13}{*}{ 意思決定回数（回） } & 700 & $-0.25 \%$ & $-0.22 \%$ & $-0.59 \%$ & $-0.32 \%$ \\
\hline & 750 & $-0.16 \%$ & $-0.12 \%$ & $0.24 \%$ & $3.62 \%$ \\
\hline & 800 & $-0.21 \%$ & $-0.39 \%$ & $-0.08 \%$ & $0.80 \%$ \\
\hline & 850 & $-0.23 \%$ & $0.04 \%$ & $-0.16 \%$ & $4.02 \%$ \\
\hline & 900 & $-0.22 \%$ & $-0.08 \%$ & $0.06 \%$ & $0.20 \%$ \\
\hline & 950 & $-0.20 \%$ & $0.06 \%$ & $-0.05 \%$ & $0.16 \%$ \\
\hline & 1,000 & $0.00 \%$ & $0.00 \%$ & $0.00 \%$ & $0.00 \%$ \\
\hline & 1,050 & $-0.32 \%$ & $0.05 \%$ & $-0.56 \%$ & $1.55 \%$ \\
\hline & 1,100 & $-0.20 \%$ & $0.04 \%$ & $-0.15 \%$ & $1.27 \%$ \\
\hline & 1,150 & $0.02 \%$ & $0.07 \%$ & $-0.26 \%$ & $3.74 \%$ \\
\hline & 1,200 & $-0.22 \%$ & $0.13 \%$ & $-0.21 \%$ & $3.63 \%$ \\
\hline & 1,250 & $0.01 \%$ & $0.27 \%$ & $-0.45 \%$ & $2.58 \%$ \\
\hline & 1,300 & $-0.10 \%$ & $0.08 \%$ & $-0.22 \%$ & $1.56 \%$ \\
\hline \multicolumn{2}{|c|}{$\begin{array}{c}\text { 意思決定回数が } 1,000 \text { 回の場合の } \\
\text { プロジェクト価値 }\end{array}$} & 148.94 & 214.50 & 57.43 & 5.94 \\
\hline
\end{tabular}

定回数について 50,000 本のサンプルパスから期間が 1 年間のプロジェクトの価值を求めることを 10 回 行い, その平均值と意思決定の回数が 1,000 回の平均值との変化率を表している（例えば，意思決定回 数が $n$ 回の場合のプロジェクト価值の平均值を $V_{n}$ とすると, 表の值は

$$
\frac{V_{n}-V_{1000}}{V_{1000}} \times 100
$$

として算出される）。表 1 は各パターンと各意思決定回数におけるプロジェクト価值の変化率を示す. 表 1 より，いずれのケースにおいても意思決定回数が 1,000 回との差は非常に小さくなることが読み取れ, 十分に連続的な意思決定の近似と考えられると判断した。

\section{謝辞}

本稿を作成するに当たり, 査読者の方々や編集委員の方から有益なコメントを頂きました，この場を借 りて深くお礼を申し上げます。なお本研究は，科研費基盤研究 B (YYK5B02) の助成を受けたものです.

\section{参考文献}

[1] Bessembinder, H., Coughenour, J. F., Seguin, P. J. and Smoller, M. M. (1995): Mean reversion in equilibrium asset prices: Evidence from the futures term structure, Journal of Finance, 50, $361-375$.

[2] Dixit, A. (1989): Entry and exit decisions under uncertainty, Journal of Political Economy, 97, 620-638. 
[3] Longstaff, F. A. and Schwartz, E. S. (2001): Valuing american options by simulation: A simple least-squares approach, Review of Financial Studies, 14, 113-147.

[4] McDonald, R. L. and Siegel, D. (1986): The value of waiting to invest, Quarterly Journal of Economics, 101, 707-727.

[5] Metcalf, G. E. and Hassett, K. A. (1995): Investment under alternative return assumptions comparing random walks and mean reversion, Journal of Economic Dynamics and Control, 19, $1471-1488$.

[6] Sarkar, S. (2003): The effect of mean reversion on investment under uncertainty, Journal of Economic Dynamics and Control, 28, 377-396.

[7] Tsekrekos, A. E: (2010): The effect of mean reversion on entry and exit decisions under uncertainty, Journal of Economic Dynamics and Control, 34, 725-742.

[8] 今井潤一 (2004): 「リアル・オプション: 投資プロジェクト評価の工学的アプローチ」, 中央経済社.

[9] 諸田崇義 (2010): “コモディティ価格変動の特徵とプライシング・モデルの展開”, 金融研究, 29, 27-72. 